\title{
Comparison of Regeneration and Yield Status between Community Forest and Collaborative Forest
}

\author{
Pitamber Gaire ${ }^{* 1}$, Pramod Ghimire ${ }^{1}$ \\ ${ }^{1}$ Agriculture and Forestry University, Faculty of Forestry, Hetauda, Nepal \\ *Corresponding author (Email: pitambergaire3@gmail.com)
}

How to cite this paper: Gaire, P. and Ghimire, P. (2019). Comparison of Regeneration and Yield Status between Community Forest and Collaborative Forest. Grassroots Journal of Natural Resources, 2(1-2): 26-36. Doi:

https://doi.org/10.33002/nr2581.6853.02123

Received: 24 April 2019

Reviewed: 01 May 2019

Provisionally Accepted: 10 May 2019

Revised: 12 May 2019

Finally Accepted: 20 May 2019

Published: 20 June 2019

Copyright $\odot 2019$ by author(s) and

The Grassroots Institute.

This work is licensed under the Creative Commons Attribution International License (CC BY 4.0).

http://creativecommons.org/licenses/by/4.0/
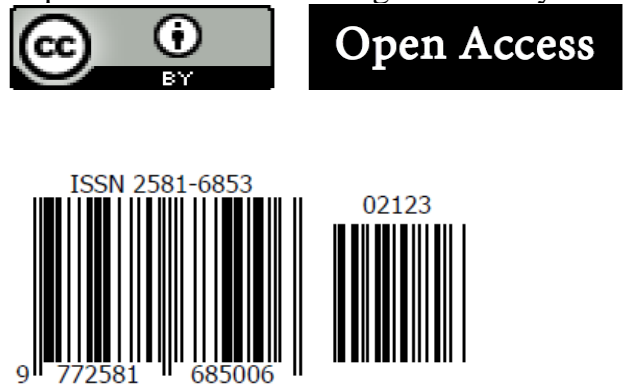

\begin{abstract}
The present article primarily addresses the silvicultural system (i.e., irregular shelter wood system) in Sal forest adopted in both community and collaborative forest in Kapilbastu district of Nepal. Systematic sampling with 0.5 percent sampling intensity along with statistical tools like SPSS and MS-Excel were used for resource inventory and data analysis, respectively. The result of the study shows notable increase in seedling status during the first year (2015/16) in community forest. A decrease in sapling number during the second year (2016/17) was noticed in Tilaurakot collaborative forest at its initial level of implementation. At the same time, community forest has higher yield status with a smaller number of trees felled in Tilaurakot collaborative forest under regeneration felling. The regeneration status of species varied insignificantly $(\mathrm{p}>0.05)$ between the community forest and Tilaurakot collaborative forest. A recommendation is made for proper implementation of irregular shelter wood system for managing the existing degraded Sal forests of the Terai region of Nepal; however, its long-term effects on plant species diversity should also be further studied in detail.
\end{abstract}

\section{Keywords}

Regeneration; Yield; Community forest; Collaborative forest; Silvicultural system 
Doi: https://doi.org/10.33002/nr2581.6853.02123

\section{Introduction}

An integrated approach to forestry development and conservation have emerged in Nepal with new names like "community forestry" (CF) and "collaborative forest" $(\mathrm{CbF})$. Community forests in Nepal have been managed under traditional felling system, which states that regeneration and felling are distributed throughout the designated plots (DoF, 2017). The management practice in collaborative forest is irregular shelter wood, which is the most suitable for ensuring regeneration in forests having canopy dominants (Peluso and Padoch, 1996). Both uniform and irregular shelter wood systems have been developed and successfully implemented in Nepal (Chengappa, 1944).

The irregular shelter wood system has no periodic blocks, regeneration period being indefinite but long one. The regeneration areas are scattered and are re-allotted every 10 years. This system works not only in regard to the selection of areas for felling but also in connection to the volume of material felled annually, provided that the total prescribed volume for the 10 year period is not exceeded (Bampton, Ebregt and Banjade, 2007). The regeneration is a critical part of forest management, because it maintains the desired species composition and stocking after various disturbances (Khumbongmayum, Khan and Tripathi, 2005). The regeneration of a tree species depends on the ability of its seedlings and saplings to survive and grow (Good and Good, 1972). To be sylviculturally sustainable, forest management must ensure good regeneration, maintain proper age class (age-gradation), normal increment and normal growing stock (Subedi, 2011). Various efforts have been made on developing suitable silvicultural systems while mostly in building judicious canopy opening for regeneration of Sal (Troup, 1986). The presence of sufficient number of seedlings, saplings and young trees determines the population structure that depicts satisfactory regeneration behavior. The inadequate number of seedlings and saplings of a tree species in a forest indicates poor regeneration, while their complete absence indicates no regeneration (Singh, Reddy and Singh, 1995).

The concept of yield regulation is simply conceived as the process by which the objective of sustainable yield is translated into operational forestry practice via planning, monitoring and control. Yield regulation or allocation involves making decisions that lead to clear specifications of where and under what conditions a harvest may be cut using Annual Allowable Cut (AAC) and technical information about a forest. It is critically an important part of sustainable tropical forest management (Armitage, 1998). Yield regulation is the means to achieve sustained yield. Sustained yield itself implies that products removed from the forest are replaced by growth, with or without artificial interventions such as re-planting, liberation thinning, etc. The sustained yield for both plantations and naturally regenerated or mixed-age stands was classically equated to the mean annual increment (MAI) of a normal forest (Brasnett, 1953).

Both the community and collaborative forestry programs aim at devolving authority and control over forest resources to user groups, especially, with distant and proximate users. The main focus is on meeting the fuelwood and fodder requirements of local communities, their participation, livelihood improvement, income generating activities, gender equity and governance system (Sharma, 2007). No active silvicultural interventions are practiced, except in a few small research plots (Pokharel and Amatya, 2000). The present article provides additional information to submit recommendations pertaining to the management of community and collaborative forests based on the assessment of their regeneration and growth conditions of the forest for the overall sustainable development of forest areas.

Pitamber Gaire, Pramod Ghimire 


\section{Materials and Methods}

To study the seedlings and saplings, the sample plot of $2 \mathrm{~m} \times 2 \mathrm{~m}$ were laid out only in the annual felling areas for regeneration survey based on the principle of systematic sampling with the help of ArcGIS 10.2 (Scientific Forest Management Guideline, 2014). Altogether, 42 and 51 sample plots were laid out in the annual felling area of 2015/16, 2016/17 and 2017/18 in community forest and Tilaurakot collaborative forest for regeneration survey with $0.5 \%$ sampling intensity, respectively, excluding herbs or climber layers. T-test statistics was employed for data analysis using the average of the seedling and sapling found in all those sample plots.

Cottas and quarter girth formula was used to estimate and calculate the exact volume of timber and firewood from the regeneration felling. Mean annual increment was calculated as the incremental volume growth $(\mathrm{Vt})$ over a period $(\mathrm{T})$ from the last harvest.

Mean Annual Increment $(\mathrm{MAI})=$ Increment/Age

The AAC will be then be calculated as:

$A A C=(1-D \%) * M A I$

Where:

$\mathrm{D} \%=\mathrm{D} /(\mathrm{Y}+\mathrm{D})$

$\mathrm{D}=$ Felling damage (July, 1999)

Similarly, Yield was calculated as:

Either with, Hanjlik formula $=(\mathrm{V} / \mathrm{R})+(\mathrm{i} / 2)$

$\mathrm{V}=$ Volume

$\mathrm{R}=$ Rotation period

Or, Cottas formula $=(\mathrm{V} / \mathrm{P})+(\mathrm{i} / 2)$

$\mathrm{V}=$ Volume

Where,

$\mathrm{P}=$ Regeneration period

$\mathrm{i}=$ increment for both the cases.

Similarly, independent two sampled t-test assuming equal variance was used for testing significant differences in the regeneration status between community forest and collaborative forest at $95 \%$ confidence interval.

\section{Results and Discussion}

\section{Regeneration Status}

This section presents regeneration status of both seedling and sapling which may have a role in determination of dominant forest species in the studied area. 


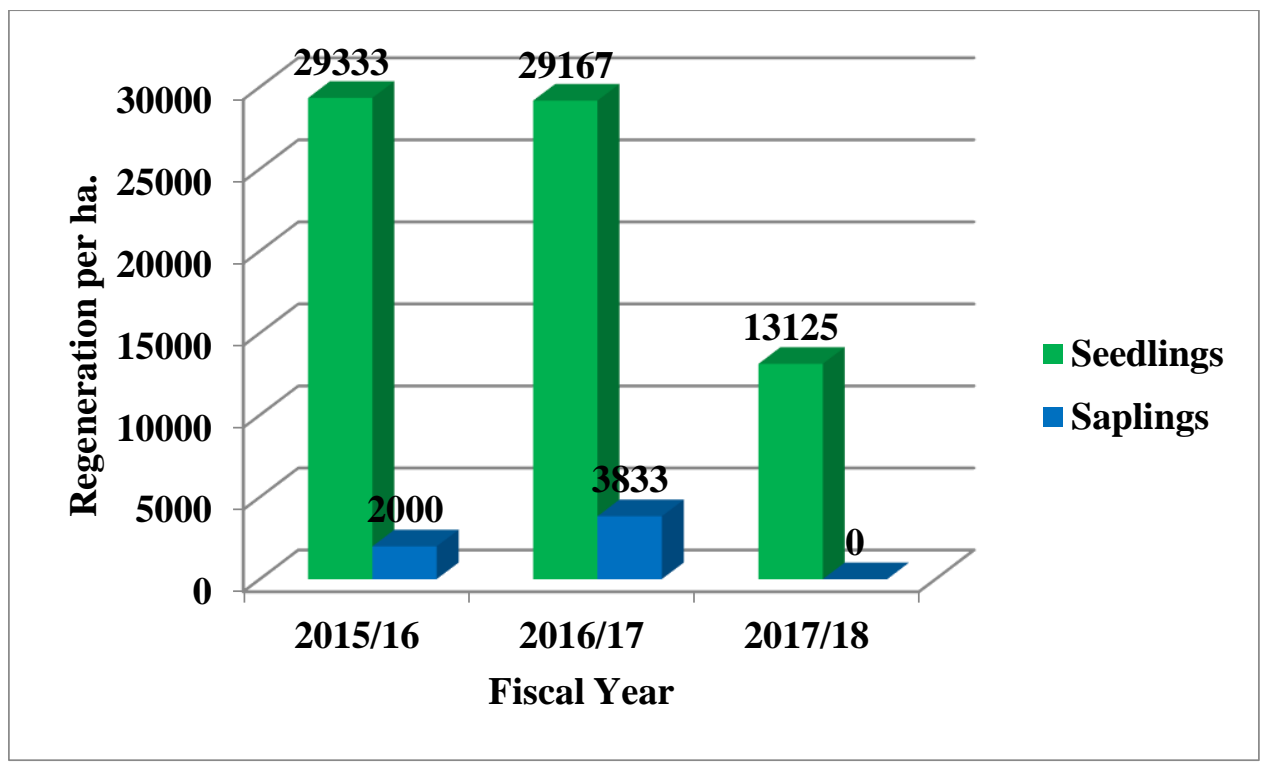

Figure 1: Fiscal year wise Regeneration Status of Community Forest

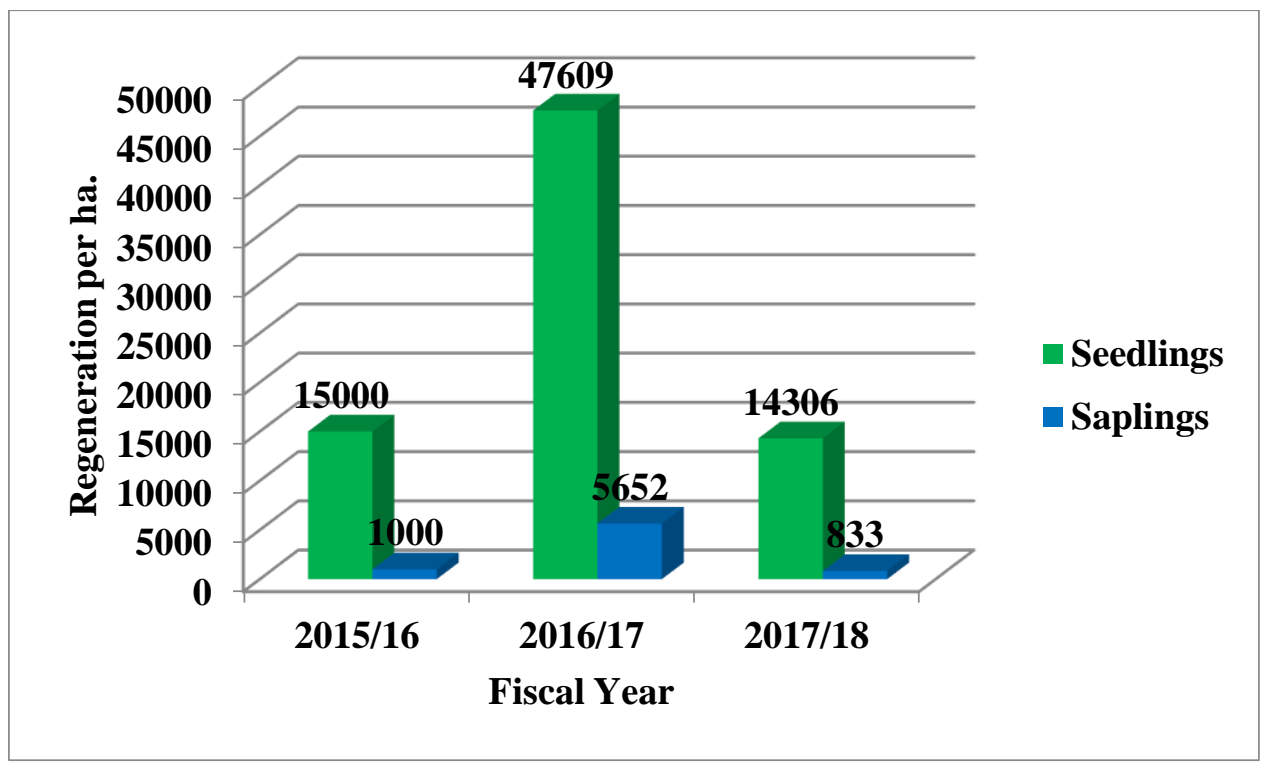

Figure 2: Fiscal year wise Regeneration Status of Collaborative Forest

Figure 2 and 3 present the regeneration status (i.e. seedling and sapling) of the study area. The status of seedling and sapling in the first year (i.e. Fiscal Year 2015/16) is 29333/ha and 2000/ha, and sapling is 15000/ha and 1000/ha in community forest and collaborative forest, respectively. Collaborative forest $(\mathrm{CbF})$ has a lower number of seedling and sapling in the first year as compared to community forest (CF). Similarly, the status of seedling and sapling is found to be $13125 / \mathrm{ha}$ and 0/ha and 14306/ha and 833/ha in CF and CbF in third year (i.e. FY 2017/18), respectively. 

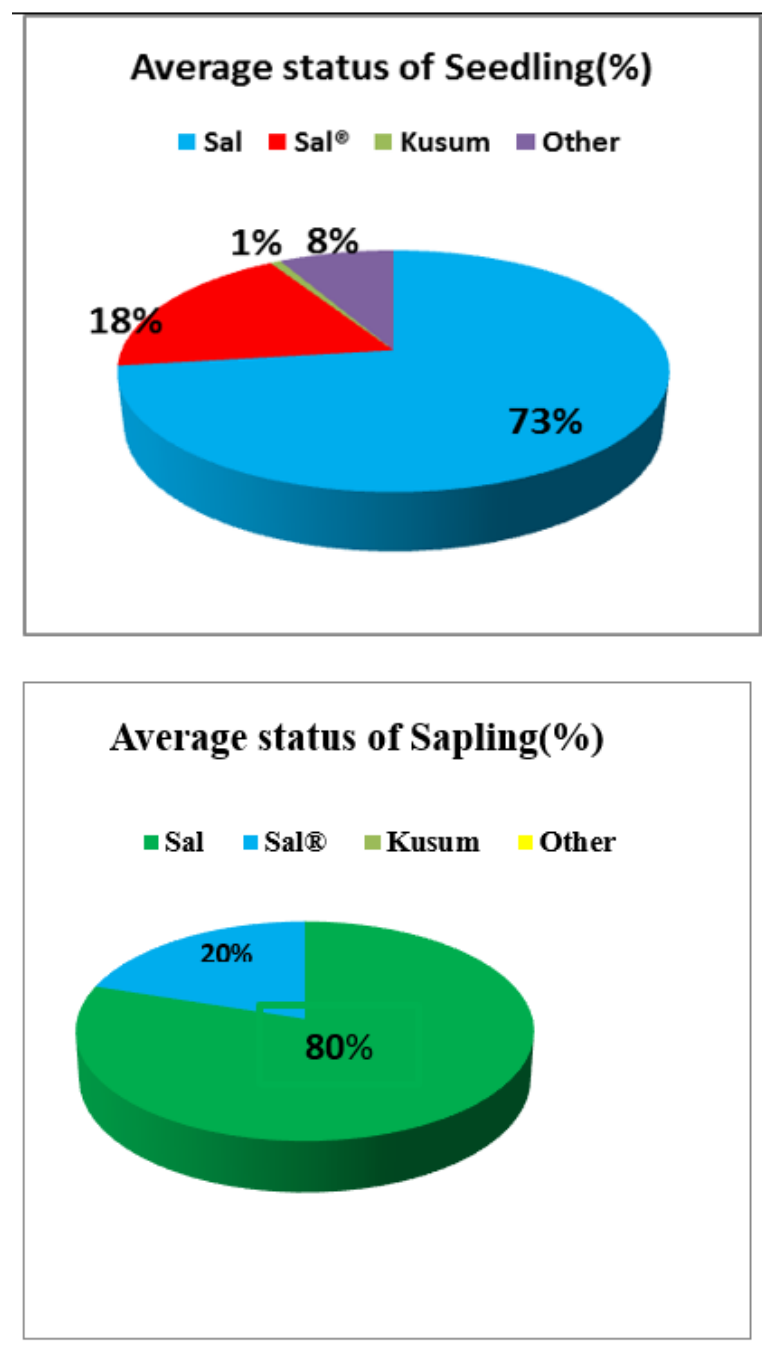

Nawajagriti CF

\section{Average status of Seedling(\%)}

- Sal(s) $\square$ Sal(r) Kaachari $₫$ Jamun $\square$ Other
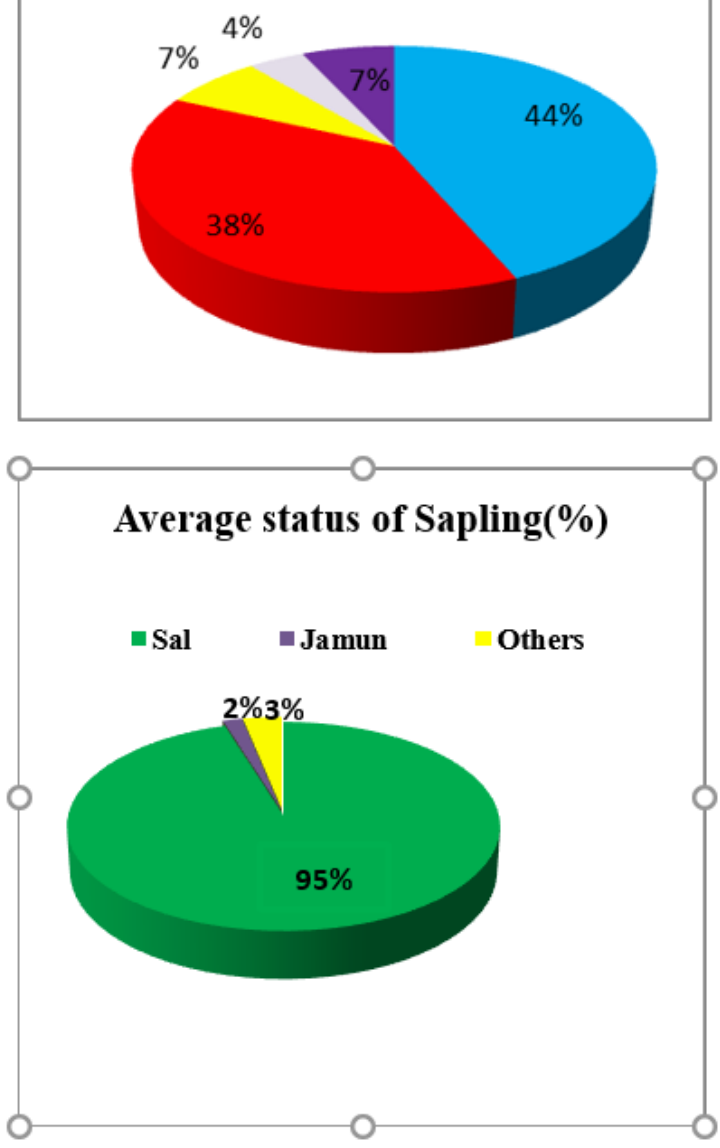

Tilaurakot CbF

Figure 3: Percentage covers of species in community

Average Status of Seedlings and Saplings (\%) in the Study Area

Based on the occurrence of tree species in different stages, two categories of seedlings and saplings were sampled: (a) those represented in the seedling stage (less than $1 \mathrm{~m}$ height); and (b) those represented in the advanced sapling stage $(5-10 \mathrm{~cm}$ diameter at breast height) as shown in the Figure 3. The seedling and sapling population in collaborative forest was collectively dominated by Shorea robusta, Syzygium cumini, Schleichera oleosa, Terminalia tomentosa, Mallotus philippensis and Cornus oblonga, while Shorea robusta, Schleichera oleosa,Psidium guajava and Leucaena leucocephala dominated the seedling and sapling population in community forest. Out of the total seedling species, i.e. $601(\mathrm{CbF})$ and $414(\mathrm{CF})$, the regenerating species Sal accounted for about $82 \%$ and $91 \%$, respectively, in the three consecutive fiscal years 2015/16, 2016/17 and 2017/18. Similarly, out of the total sapling species, i.e. 62 (CbF) and $35(\mathrm{CF})$, the regeneration of Sal accounted for $95 \%$ in $(\mathrm{CbF})$ and $100 \%$ sapling of Sal combining both regeneration from seed 
and root sucker in case of $(\mathrm{CF})$. Some species that occurred solely at the advanced regeneration stage were also among the rarest species; these were Phyllanthus emblica and Pterocarpus marsupium in both the cases.

\section{Result of Statistical Test}

The result of independent two sampled t-test shows that there is no significant difference in the status of regeneration between community forest and collaborative forest at $95 \%$ confidence interval with $p$ value $0.939(p>0.05)$. The result revealed that the forest management regime, i.e. community forestry and collaborative forest management, does not affect the number of regeneration status.

\section{Yield Status}

Yield from annual felling area of both $\mathrm{CF}$ and $\mathrm{CbF}$ on three consecutive fiscal years is shown in Figure 4. The figure shows that volume of timber harvested has increased gradually from 2015/16 to 2017/18 with the latest harvest from CF and CFM being 4492.32 cubic feet and 4640.43 cubic feet, respectively, from 80 felled trees in $\mathrm{CF}$ and 132 trees felled in $\mathrm{CbF}$ (Table 1).

Table 1: Number of trees felled in $\mathrm{CF}$ and $\mathrm{CbF}$ in each Fiscal Year

\begin{tabular}{lll}
\hline Fiscal Year & Number of trees felled $(C F)$ & Number of trees felled $(\mathrm{CbF})$ \\
\hline $2015 / 16$ & 74 & 123 \\
\hline $2016 / 17$ & 82 & 127 \\
\hline $2017 / 18$ & 80 & 132 \\
\hline
\end{tabular}



Figure 4: Fiscal year wise yield status of Community forest and Collaborative forest 


\section{Discussion}

The results indicate higher seedling and sapling number in the collaborative forest Block-4 Compartment-3 Sub-compartment-8 (B4C3S8), which could be the result of regeneration felling as compared to that in the community forest Compartment-1 Sub-compartment-1 (C1S1). The status of seedling was found to be 29333/ha and 15000/ha, 29167/ha and 47609/ha, and 13125/ha and 14306/ha in CF and CbF in the consecutive fiscal year 2015/16, 2016/17 and 2017/18, respectively. Similarly, the status of sapling was found to have 2000/ha and 1000/ha, 3833/ha and 5652/ha and 0/ha and 833/ha in CF and CbF in fiscal year 2015/16, 2016/17 and 2017/18, respectively, with $S$. robusta as the dominant forest species. The difference in regeneration status is because of intensive grazing, illegal felling and logging, lack of cleaning operation and advance growth of invasive species in the annual felling area of $\mathrm{CbF}$. But, all these operations and management practices were significantly carried out by the user group of CF. Tilaurakot collaborative forest, after realizing the importance of management operations in the promotion and advance growth of seedling and sapling incorporated a management practice like the application of fencing to check grazing, clearing of unwanted grasses, etc. As a result, the regeneration got sorted in the following years as shown in the figure above.

The result of independent two sampled t-test shows that there is no significant difference. But the actual regeneration status between community forest and collaborative forest management is different. Differences, in many cases, are accounted for many reasons, like soil condition, variation in canopy opening, improper allocation of mother trees and disturbance in past condition (Malik and Bhatt, 2016). In this study, variation in regeneration status has been critically analyzed and verified through two perspectives.

\section{1) Expert Opinion}

- Seed year: Although Sal trees produces seed every year, good seed year is normally every third year. Seed production in Sal varies (up to $500 \mathrm{~kg} \mathrm{ha}^{-1}$ was recorded during the early 1980 s) from year to year and from tree to tree. Seeding is normally from mid-May to midJune. Its viability is just a week.

- Canopy opening: Forests or woodlands in which the individual tree crowns do not overlap to form a continuous canopy layer but are more widely spaced, leaving open sunlight areas within the woodland.

- Die back: Mortality of Sal is occurring in Terai forest of Nepal with die back and complete death of Sal trees in patches resulting in the development of root sucker.

- Seed dormancy: It is a state in which seeds are prevented from germinating even under environmental conditions. These conditions are a complex combination of water, light, temperature, gasses, mechanical restrictions, seed coats, and hormone structures.

- Disturbance: Disturbance is often touted as a management tool. A moderate disturbance is believed to enhance diversity; thus, an understanding of frequent and fluctuating disturbance regimes in forests and their effects on stand structure, dominance and diversity is very crucial.

- Grazing: Grazing animals often browse on small plants and their twigs. Similarly, trampling is the main effect by animals leading to soil compaction and resulting in decrease in soil moisture. 


\section{2) User group}

- Illegal felling and logging: Improper felling practice has resulted in death of immature seedlings and saplings.

- Fuel wood and litter collection: For meeting peoples' daily need, the effect on the status of regeneration was seen massive.

- Lack of controlled burning: Prescribed or controlled burning is a technique sometimes used in forest management, farming, or prairie restoration. Fire is a natural part of both forest and grassland ecology and controlled fire can be a tool for foresters as a succession tool. But there wasn't the practice of using fire as a management tool.

- Higher grazing intensity: Most of the local people are dependent on livestock for the economic purpose. For this, community forest is the ultimate source of fodder and forage required for livestock. High dependency and increased grazing intensity has endangered the long-term stability of regeneration by reducing the height and the number of leaves per seedling.

- Lack of technical manpower to control invasive species: Invasive alien species affect native species mainly through predation, competition and habitat modification. Invasion and rapid expansion of some alien species, such as Mikania micrantha, Ageratina adenophora, Chromolaena odorata and Lantana camara has emerged as a major threat to a forest species especially regeneration. However, community forest is lacking technical manpower and technologies to control the invasion of these species.

Halpern and Spies (1995) found that other management activities (fertilization, herbicide application, grazing) can affect upon the species composition of vegetation in addition to the initial effect of logging and site preparation. Suoheimo (1999) observed 50,000-100,000 seedlings/ha after regeneration felling of Sal forests under uniform shelter wood system in Terai region of Nepal. Both shoot and root development of $S$. robusta was also observed better in open space rather than under shade (Troup, 1986). The regeneration of dominant forest species 'Sal' is satisfactory at seedling stage, but their development into sapling is very poor. However, the overall regeneration status was fairly high in the study area as compared to the Community Forest Inventory Guideline (2004).

Table 2: Regeneration condition of the forest

\begin{tabular}{|l|l|l|l|}
\hline \multicolumn{4}{|l|}{ Regeneration Condition of Forest } \\
\hline Criteria & Good & Medium & Poor \\
\hline No. of Seedling & More than 5000 per ha & $(2000-5000)$ per ha & Less than 2000 per ha \\
\hline No. of Sapling & More than 2000 per ha & $(800-2000)$ per ha & Less than 800 per ha \\
\hline
\end{tabular}

Source: Community Forestry Inventory Guideline, 2004

Mohammadi et al. (2008) observed low value of species diversity in the natural stand as compared to the managed stand with shelter wood system in Loveh forest of Iran. In Nepal both $\mathrm{CF}$ and $\mathrm{CbF}$ were managed with regeneration felling followed by post-harvest performed in the first, second and third successive years. In other areas the management was carried out with only regeneration felling during this study period. Forest structure and diversity varied with different silvicultural treatments applied on it. Battles et al. (2001) found higher regeneration status in plantation and shelter wood regime than in single tree and reserve stands through their number varied from year to year under group selection system. It is a well known fact that the disturbance plays an important

Pitamber Gaire, Pramod Ghimire 
role in species diversity and composition. The intermediate disturbance hypothesis is most applicable for forest management. Controlled disturbance prevents few species from dominating in an ecosystem. The composition of species with its richness and evenness relies on two separate aspects of silviculture: i) canopy cover, and ii) seed bed characteristics. Canopy cover is a function based on timing and amount of wood harvested whereas the seed bed characteristics is related with post harvesting site preparation at the same time. $\mathrm{CbF}$ is a stand managed under both aspects of silviculture while CF is a stand managed with no seed-bed treatment (only harvesting) except in few areas.

\section{Comparison of Regeneration of S. robusta with Other Species}

The seedling status of $S$. robusta was found to be $91 \%$ higher in the Nawajagriti CF than in Tilaurakot CbF. Similarly, its sapling density was also found to be $100 \%$ if Sal is homogeneous regeneration. The mean seedling and sapling status of $S$. robusta per hectare varied remarkably between $\mathrm{CF}$ and $\mathrm{CbF}$, revealing significance of scientific forest management as far as regeneration is concerned. While the mean seedling status of other species remained low between the managed blocks in response to intervention, their mean sapling status was found to be slightly higher in the $\mathrm{CbF}$. In Nepal, sustainable regeneration of $S$. robusta has been reported from both the Terai and the hills which were not observed among natural dense forest with a high density of larger trees (Rautiainen, 1996). The regeneration of most of the species is favored by disturbance of moderate intensity, which may be subjected to poor in low and heavily disturbed forest (Sapkota, Tigabu and Oden, 2009). S. robusta has been facing a serious threat to its existence in the tropical and subtropical belts of India due to infestation by Sal borer (Hoplocerambyx spinicornis) and also to moisture stress caused by the combined effects of intensive grazing, repeated fire, lopping and canopy opening or threshold light intensity for the process of photosynthesis in seedlings. A wide range of biotic and abiotic factors are responsible for large scale death of seedlings and saplings of $S$. robusta leading to its poor regeneration. Since, the area under community forest was fenced, i.e. protected against biotic factors, it can be assured that abiotic factor was dominant in growth of seedlings in the collaborative forest; and, therefore, further detailed study is needed.

\section{Comparison of Yield Between the Two Regimes}

Although, the $\mathrm{CF}$ has a smaller number of trees felled as compared to $\mathrm{CbF}$, harvested volume is quite higher. This is because of good quality of stems present in the site with its significant effect shown on the volume of firewood. Good stems yield less volume of firewood with a smaller number of trees felled shown in figure 4. This phenomenon is just reverse in case of Tilaurakot collaborative forest. The volume and firewood harvested in accordance with the number of trees felled is also helpful in knowing the composition of the forest in the past. However, the overall growing stock was low in the study area as compared to the data of national forest status of Nepal.

Table 3: Forest condition on the basis of growing stock and regeneration

\begin{tabular}{|c|c|c|c|c|c|c|c|c|}
\hline $\begin{array}{c}\text { Total Stock } \\
(\text { Poles }+ \text { Trees })\end{array}$ & \multicolumn{2}{|c|}{$\begin{array}{l}\text { More than } 7000 \text { cubic } \\
\text { ft/ha or }\left(>200 \mathrm{~m}^{3}\right)\end{array}$} & \multicolumn{3}{|c|}{$\begin{array}{c}(2000-7000) \text { cubic ft/ha } \\
\text { or }\left(50-200 \mathrm{~m}^{3}\right)\end{array}$} & \multicolumn{3}{|c|}{$\begin{array}{c}\text { Less than } 2000 \text { cubic } \\
\text { ft/ha or }\left(<50 \mathrm{~m}^{3}\right)\end{array}$} \\
\hline on & & & & & & & & \\
\hline 0 & 1 & $M$ & 0 & Medium & Poor & 1016 & 1 I OOI & Poor \\
\hline
\end{tabular}

Source: Community Forest Inventory Guideline (2004) 
Doi: https://doi.org/10.33002/nr2581.6853.02123

\section{Conclusion}

The regeneration of 'Sal' is satisfactory at seedling stage, but its development into sapling is very poor. The result of t-test shows that there is no significant difference in regeneration status between community forest $(\mathrm{CF})$ and collaborative forest $(\mathrm{CbF})$ at $95 \%$ confidence interval with p-value $0.939(\mathrm{p}>0.05)$ and $\mathrm{p}$-value $0.49(\mathrm{p}>0.05)$ for both seedling and sapling, respectively. However, the actual regeneration status between community forest and collaborative forest is different. The experts and user groups have critically verified the variation in regeneration status. The result of the regeneration status showed a decreasing trend in community forest as compared to the collaborative forest. Inclusion of technical manpower, controlling of grazing and proper forest management operations such as canopy opening, thinning, pruning and weeding led to the successful increment of regeneration in collaborative forest.

The yield has increased gradually from 2015/16 to 2017/18 with the latest harvest from community forest and collaborative forest being 4492.32 cubic feet and 4640.43 cubic feet, respectively, from 80 felled trees in $\mathrm{CF}$ and 132 trees felled in CbF. Variation in yield from two different regimes was accounted as a result of previous growing stock, good stem quality and presence of immature/overmature trees.

Hence, this study strongly recommends the application of sustainable forest management activities, as practiced under collaborative forest management and community forest management. The regeneration of tree species in both the forest management areas is good. The future communities of tree species in community forest may be sustained if there is not any major environmental stress or biotic pressure. The regeneration status of tree species recorded from the present study may provide baseline information for understanding pattern of population and formulating conservation and management strategies that would help forest management and conservation of the species.

\section{Acknowledgement}

The authors gratefully acknowledge Tilaurakot Collaborative Forest Management Committee (TCFM-C) for providing fund to conduct this research work. We would like to express our deepest gratitude for all the concern people and institutions for their significant contribution and support for the successful completion of this research work.

\section{References}

Armitage, I. (1998). Guidelines for the management of tropical forests. 1. The production of wood. FAO Forestry Paper, 135: 293.

Bampton, J.F.R., Ebregt, A. and Banjade, M.R. (2007). Collaborative Forest Management in Nepal's Terai: Policy, Practice and Contestation. Forest and Livelihood, 6(2): 30-43.

Battles, J.J., Shlisky, A.J., Barrett, R.H., Heald, R.C. and Allen-Diaz, B.H. (2001). The effect of forest management on plant species diversity in a Sierran conifer forest. Forest Ecology and Management, 146: 211-222.

Brasnett, NV. (1953). Planned Management of Forests. London: George, Allen \& Unwin Ltd., pp.128-135.

Chengappa, B.S. (1944). The Andaman forests and their regeneration. The Indian Forester, 70: 450- 611.

Pitamber Gaire, Pramod Ghimire 
DoF (Department of Forests) (2017). Management Information System. Department of Forests, Kathmandu, Nepal.

Good, N.F. and Good, R.E. (1972). Population dynamics of tree seedlings and saplings in mature Eastern hardwood forest. Bulletin of Torrey Botanical Club, 99: 172-178.

Halpern, C.B. and Spies, T.A. (1995). Plant species diversity in natural and managed forests of the Pacific Northwest. Ecological Application, 5-(4): 913-934.

July, C.R. (1999). Some Issues in the Yield Regulation of Moist Tropical Forests Paper presented to a workshop on Humid and semi-humid tropical forest yield regulation with minimal data held at CATIE, Turrialba, Costa Rica, 5-9 July 1999.

Khumbongmayum, A.D., Khan, M.L. and Tripathi, R.S. (2005). Survival and growth of seedlings of a few tree species in the four sacred groves of Manipur, Northeast India. Current Science, 88: 1781-1788.

Malik, Z.A. and Bhatt, A.B. (2016). Regeneration status of tree species and survival of the Seedlings in Kedarnath wildlife sanctuary and its adjoining areas in Western Himalaya, India. Tropical Ecology, 57(4): 677-690.

Muhammadi, J., Shataee, S., Habashi, H. and Amiri, M. (2008). Effects of shelterwood logging on diversity of tree species in Loveh Forest, Gorgan. Iranian Journal of Forest and Poplar Research, 16 (2): 241-250.

Peluso N.L. and Padoch, C. (1996). Changing Resource Rights in Managed Forests of West Kalimantan. In: Padoch, C. and Peluso, N.L. (eds), Borneo in Transition: People, Forests, Conservation and Development, Singapore: Oxford University Press, pp.121-136.

Pokharel, B.K. and Amatya, S.M. (2000). Community Forestry Management Issues in the Terai. Issue Paper 9, Kathmandu: Joint Technical Review Committee on Community Forestry. Ministry of Forest and Soil Conservation, His Majesty Government of Nepal (HMGN).

Rautiainen, O. (1996). Regeneration status of Sal (Shorea robusta Gaertn. F.) in Bara district, Nepal. Banko Janakari, 6 (1): 26-32.

Sapkota, I.P., Tigabu, M. and Oden, P. C. (2009). Spatial distribution, advanced regeneration and stand structure of Nepalese Sal (Shorea robusta) forest subject to disturbance of different intensities. Forest Management and Ecology, 257: 1966-1975.

Sharma, B.K. (2007). Forestry Credit in Nepal. Kathmandu, Nepal, p.13.

Singh, A., Reddy, V.S. and Singh, J.S. (1995). Analysis of woody vegetation of Corbett National Park, India. Vegetation, 120: 69-79.

Subedi, V.R. (2011). Forest Management Opportunities and Challenges in Nepal. The Nepal Journal of Forestry, 14: 95-110.

Suoheimo, J. (1999). Natural regeneration of Sal (Shorea robusta) in the Terai region, Nepal. University of Helsinki, Helsinki, Finland.

Troup, R.S. (1986). The Silviculture of Indian Trees. Dehradun, India: International Book Distributors. 